\title{
Alchemy under James IV of Scotland *
}

\begin{abstract}
TAMES IV of Scotland was one of the most in. telligent princes in Europe at the beginning of the sixteenth century. He had an active and inquiring mind, and sought to extend his knowledge by observation and experiment. His interests included medicine and surgery, physiology, alchemy, and even psychology. Thus, in 1493, he tried to determine by a direct experiment the nature of that "primitive tongue" which Ben Jonson, at a later day and in jocular mood, supposed to be High Dutch. "The king gart [caused] tak ane dum woman and pat hir in Inchekeytht [island]", wrote Lindesay of Pitscottie, "and gaif hir tua young bairnes, and gart furmische them of meit, drink, fyre and candell, claithis [clothes], witht all uther kynd of necessaris, desyrand to knaw quhat langage thir bairnes wald speik quhene they came to lauchfull aige. Sum sayis they spak goode hebrew bot as to my self I knaw
\end{abstract} not."

James's excursions into alchemy were probably determined by his interest in medicine, because of the potent medicinal and rejuvenating virtues which were ascribed to the Philosopher's Stone. His chief associate in a prolonged series of alchemical experiments was a certain John Damian, an ingenious and personable Italian or Frenchman. Under Damian's inspiration and direction, James established Scotland's first research laboratory in Stirling Castle.

James provided his alchemist with an emolument and the necessary leisure for research by creating him Abbot of Tungland, in Galloway. The new ecclesiastical dignitary preferred the smells of his laboratory to the odour of sanctity, and feared the effect of the laboratory smoke upon his costly religious vestments.

The accounts of the Lord High Treasurer of Scotland from 1501 to 1513 throw some interesting light upon the nature and cost of the materials which Damian and his associates used in their attempts to prepare the quinta essencia (Philosopher's Stone, or Elixir of Life). Among them were gold, silver, quick-

* Abstract of a lecture delivered to the Society for the Study of Alchemy and Early Chemistry on May 11, at the British Academy, Burlington Gardens, Iondon, W.1, by Prof. John Read, F.R.S. silver, aqua vitæ, saltpetre, sal ammoniac, litharge, salt and sugar. The prices of apparatus, the wages of the laboratory attendants, and even the cost of the alchemist's attire, are detailed in the Treasurer's records.

Three kinds of aqua vitæ, or whisky, are indicated by the adjectives "small", "ordinary" and "thricedrawn". Although in the strange Scotland of James IV whisky must have been a rare drug reserved mainly for medicinal purposes, the Abbot of Tungland and his collaborators in the Great Work were able to secure and find uses for surprisingly large amounts.

Among occasional visitors to the Stirling laboratory was one Broun, a master "potingair of Sanctandrois". Skilled in the distillation of "waters" perfumed with essential oils, and also in the primitive sugar "potingry" of those times, this worthy apothecary was the unconscious prototype of the St. Andrews chemists of a later age.

The Abbot's attempts to achieve the Stone were interrupted in 1507, as a result of another of his spectacular activities. In the quaint language of Bishop Lesley: "This Abbott tuik in hand to flie with wingis ; and to that effect he causet mak ane pair of wingis of fedderis". Equipped with these movable feathered wings, he took off from the lofty battlements of Stirling Castle for a flight to Paris; "bot shortlie he fell to the ground and brak his thee bane". Nothing daunted, the courageous experimenter ascribed his downfall "to that thair was sum hen fedderis in the wingis", which yearned and coveted the midden and not the skies : if the wings had been made entirely of eagles' feathers, they would have exerted a natural tendency to soar into the heavens!

The alchemical experiments in Stirling Castle were continued until 1513, when the interest of the Scottish crown in alchemy came to an untimely end with the death of James IV upon the tragic field of Flodden. A century and a half later this interest in science found a rebirth in two of James's distant descendants-Prince Rupert of Bavaria and King Charles II.

\section{Aeronautical Research in Australia}

$\mathrm{T}$ HE growth of civil aviation and the necessity for increased attention to Air Force requirements led the Australian Government last year, at the instance of the Council for Scientific and Industrial Research, to invite $\mathbf{M r}$. H. E. Wimperis, retiring director of research to the Air Ministry, to visit the Commonwealth to examine the existing situation with a view to the inauguration of aeronautical research. His report was presented in December last and its recommendations have been generally approved by Cabinet.

It was desired that such facilities as might be provided for aero-engine work should be extended to cover automobile engines : hence the first recommendation provides for an engineering research establishment at a suitable centre (almost certainly
Melbourne), equipped for experimental work in wind tunnels, for engine tests for both aircraft and automobile use, and for physical tests of aircraft instruments and other apparatus. The laboratory will be administered by the Council for Scientific and Industrial Research, the programme of research, under a civilian superintendent, being supervised by an Australian Aeronautical Research Committee with an independent chairman. Its membership will include official representatives of the military and civil aviation departments, of meteorological services and radio communications, together with non-official members having special scientific and technical qualifications.

So far as practicable, use will be made of existing facilities at universities and in defence laboratories, 
the former being encouraged to undertake approved investigations in aeronautics for which they are fitted. It is proposed to create a chair and department of aeronautics (probably in the University of Sydney) to ensure a supply of trained personnel for military and civil aviation and for aeronautical construction. A readership in meteorology will also be established.

The Research Committee will form sub-committees to deal with aerodynamics ; power plant ; navigation and meteorology ; materials ; accidents ; and air inventions. It will also be required to investigate the use of Australian-produced materials and processes in aircraft construction; and it will maintain a general information service.

On the automobile side it is proposed to set up an Industrial Research Committee to assist the Council with advice on a programme of research and to seek the co-operation of the industry in making provision for the carrying out of it.

It will be some considerable time before the projected laboratory is completed, but a start will be made in the current financial year. Provision is being sought for $£ 143,000$ to cover capital expenditure, and the estimated annual maintenance cost is put at $£ 12,000$.

\section{Electrical Interference with Radio Reception}

$I^{\mathrm{T}}$ has been well known for some years that a large proportion of electrical apparatus and plant, of both a commercial and domestic character, produces discontinuous electrical currents, which can result in interference with radio reception over a wide range of frequencies. In view of the widespread use of broadcast receivers in everyday life, it is very much in the public interest that all possible steps should be taken to mitigate the results of such interference. In Nature of August 1, 1936, reference was made to the work of a joint committee representative of all sections of the electrical and radio industries in the study of this problem. Following the report of this committee, a number of other committees have been at work under the auspices of the British Standards Institution compiling specifications of components which may be fitted to electrical apparatus and to radio receivers with the object of reducing the nuisance of interference to a minimum. Concurrently with the operation of these committees, the Post Office on one hand and the British Electrical and Allied Industries Research Association on the other, have been carrying out investigations on a comprehensive scale.

The results of such investigations were summarized at a meeting of the Wireless Section of the Institution of Electrical Engineers on April 6, when a paper was read by Mr. A. J. Gill (of the Post Office) and Dr. S. Whitehead (of the Electrical Research Association) under the title "Electrical Interference with Radio Reception". The paper described the method of assessment of the interference to radio reception by electrical equipment, and the degree to which such interference must be reduced to permit satisfactory service. Various methods of measuring the interference have been developed in different countries and the most reliable of these have been compared with the view of securing uniformity of interpretation of the results.

With the aid of such apparatus, a study has been made of the interference produced under typically practical conditions from such electrical sources as trolley-buses, high-voltage overhead power lines, highfrequency medical apparatus and surgical equipment, electric lifts, telegraph and telephone plant, domestic appliances and the ignition systems of motor-cars. It has been found that while in some cases the interference is experienced by direct radiation from the source, it is more common for the interfering voltages to set up currents in the electrical supply network, from which the mains at the receiving station radiate locally to the receiving aerial. Following this appreciation of the nature and magnitude of the source of the interference, a detailed study has been made of methods of suppression to the level required to give satisfactory reception. Where possible, it is naturally best to suppress the interference at its source; but where this is either impracticable or unduly expensive, it is necessary to take steps to improve conditions at the receiver itself. Very effective methods of suppression have been worked out in some detail and some typical results of applying these are described in the paper. It is by the continued friendly co-operation between the electrical and radio industries that continued progress is to be anticipated as the methods of suppression and mitigation now available come into widespread use.

One of the methods adopted by the Post Office in dealing with this matter has been by co-operation with the ordinary broadcast listener in investigating complaints of interference brought to the notice of this Department. The number of such complaints brought to the attention of the Post Office has increased from some 10,000 in 1931 to nearly 50,000 in 1937. To deal with this problem, a full-time staff of about 250 are employed, and these have been trained by special courses of instruction. The equipment available to this staff comprises 110 motor-vans, each supplied with an interference locator, portable wireless receiving set, screened leads and a number of suppression components for demonstration purposes. The work of this staff has already produced a great amelioration in the conditions of broadcast reception. It is interesting to note that in some cases the broadcast listener is himself the cause of much of the interference of which he complains; for although it may not be usual in any one household to listen to broadcast programmes at the same time as the vacuum cleaner or electrically driven sewing machine is in use, these items may cause considerable interference to neighbouring listeners. Perhaps the time is not far distant when the man in the street may insist that all new domestic electrical appliances which he purchases will have been certified as 'interference free'.

The paper, to which reference was made above, concludes with an extensive bibliography, which indicates the large amount of scientific and technical work which has been devoted to this subject. 